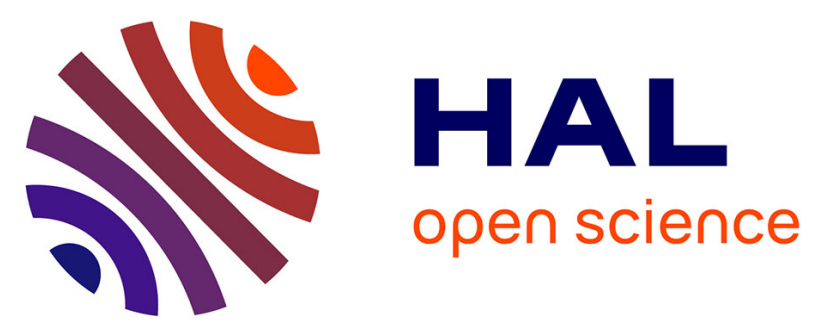

\title{
The Environment Intelligent Monitoring and Analysis for Enclosed Layer House with Four Overlap Tiers Cages in Winter
}

Hualong Li, Miao Li, Junying Li, Kai Zhan, Xianwang Liu

\section{- To cite this version:}

Hualong Li, Miao Li, Junying Li, Kai Zhan, Xianwang Liu. The Environment Intelligent Monitoring and Analysis for Enclosed Layer House with Four Overlap Tiers Cages in Winter. 11th International Conference on Computer and Computing Technologies in Agriculture (CCTA), Aug 2017, Jilin, China. pp.292-300, 10.1007/978-3-030-06179-1_30 . hal-02111515

\section{HAL Id: hal-02111515 \\ https://hal.inria.fr/hal-02111515}

Submitted on 26 Apr 2019

HAL is a multi-disciplinary open access archive for the deposit and dissemination of scientific research documents, whether they are published or not. The documents may come from teaching and research institutions in France or abroad, or from public or private research centers.
L'archive ouverte pluridisciplinaire HAL, est destinée au dépôt et à la diffusion de documents scientifiques de niveau recherche, publiés ou non, émanant des établissements d'enseignement et de recherche français ou étrangers, des laboratoires publics ou privés.

\section{(c)(1)}

Distributed under a Creative Commons Attribution| 4.0 International License 


\title{
The Environment Intelligent Monitoring and Analysis for Enclosed Layer House with Four Overlap Tiers Cages in Winter
}

\author{
Hualong $\mathrm{Li}^{1,2}$, Miao Li ${ }^{1(\varangle)}$, Junying $\mathrm{Li}^{3}$, Kai Zhan ${ }^{3}$, and Xianwang $\mathrm{Liu}^{4}$ \\ ${ }^{1}$ Institute of Intelligent Machines, Chinese Academy of Sciences, Hefei, Anhui 230031, \\ China \\ ${ }^{2}$ University of Science and Technology of China, Hefei, Anhui 230026, China \\ ${ }^{3}$ Institute of Animal Husbandry and Veterinary, Agricultural Academy of Anhui Province, \\ Hefei, Anhui 230031, China \\ ${ }^{4}$ Anhui Agricultural University, Hefei, Anhui 230026, China \\ lihualong2007@163.com, mlieiim.ac.cn
}

\begin{abstract}
This study aims at evaluating the environment quality scientifically and providing the corresponding optimization methods for facilities upgrade of enclosed henhouse with four overlap tiers cages. The intelligent environmental monitoring device for laying hens breeding was developed based on Internet of things to measure environmental parameters, including temperature, relative humidity, light intensity and $\mathrm{CO}_{2}$ concentration, wind speed, dust concentration and other environmental parameters in winter, and to analyze their impact on the laying rate and egg quality. The results showed that the environmental parameters in henhouse different measuring points were different. The height of different hens cages have a certain effect with egg-laying rate and egg weight. It can be seen that the contradiction between ventilation and heat preservation should be coordinated in winter. On the premise of keeping suitable temperature, the ventilation should be increased to provide a good production environment for laying hens.
\end{abstract}

Keywords: intelligent monitoring; cascade cage; environmental quality; laying performance

\section{Introduction}

In recent years, there were accelerating transformation and upgrading of the laying hens industry towards standardization large system in China. Due to the influence of limited land resources, rising labor costs, livestock waste problems, the proportion of cascading caged layers gradually increased. Related survey shows that, as of 2013, there were about $10.25 \%$ hens breeding farms using cascade cage in China, which generally used $4 \sim 8$ stacked cages breeding mode with automatic feeding, automatic

$\bowtie$ Corresponding author. 
collection of eggs, environmental control system and also with the transfer belt to clean up manure [1,2]. And the small and medium-sized layers farms usually adopted four cascading cage feeding mode at present. Because of the increasing breeding density, the environment control scientifically was the key point of the cascading cage layer facilities management [3,4]. In this experiment, the important environment parameters were monitored in a renovated hen house with four stacked cages in winter, and analyzed the environmental quality and its impact on the laying rate and egg quality, in order to provide scientifically references for hen house environment quality control and the facility upgrade.

\section{Materials and Methods}

\subsection{The hen house structure and building parameters}

The experiment was carried out in a 4-tier automatic controlled laminated hen house owned by Anhui Jinan poultry Co. Ltd in Anqing city, with $87.4 \mathrm{~m}$ length, $10.4 \mathrm{~m}$ width, and $5.0 \mathrm{~m}$ height, which had three columns and four aisles with $1.45 \mathrm{~m}$ width each aisle. The hen house wall is 24 brick wall, and the roof was made of $15.0 \mathrm{~cm}$ color steel structure.

Wet curtains were installed in henhouse clean end and both two sides wall. Each wet curtain area was $81.90 \mathrm{~m}^{2}$, and the thickness was $15 \mathrm{~cm}$. Ten fans (fan power 1.10 $\mathrm{KW}$ and diameter $1.10 \mathrm{~m}$ ) were located on the wall of the dirt end wall, which were divided into two layers and operated automatically by the environment controllers. There were total 30 plastic steel windows on the both two sides wall, with $1.90 \mathrm{~m} \times$ $1.10 \mathrm{~m}$ of each window area. There were 32 ventilation small windows with $1.00 \mathrm{~m} \times$ $0.20 \mathrm{~m}$ of each window area located on both two sides wall. The hen house adopted the longitudinal ventilation mode, with the plastic sheeting was used to seal the wet curtain in winter, and the fresh air entered the henhouse from the both two sides windows.

The four layers of stacked cages in henhouse were produced by Guangzhou Huanan Poultry Equipment Co. Ltd, with $600 \times 450 \mathrm{~m} \times 400 \mathrm{~mm}$ each single cage size, which could accommodate 6 laying hens. LED lights $(220 \mathrm{~V} / 5 \mathrm{~W}$, color temperature $2400 \mathrm{k} \sim 2800 \mathrm{k}$ ) were located in the middle of the each aisle, according to the install way of alternating high and low. And the distance between each lamp was $2 \mathrm{~m}$.

\subsection{The intelligent environmental monitoring device}

ARM 32-bit Cortex-M3 STM32F103VB as the core processor for the intelligent environmental monitoring device. The sensors of air temperature, relative humidity, $\mathrm{CO}_{2}$ concentration, light intensity (CG-02, Hefei Henford Electronic Technology Co. Ltd. The measurement range of air temperature: $-40{ }^{\circ} \mathrm{C} \sim+85{ }^{\circ} \mathrm{C}$, with the 
measurement accuracy: $\pm 0.3{ }^{\circ} \mathrm{C}$. The measurement range of relative humidity: $5 \%$ $95 \%$, with measurement accuracy: $\pm 2 \%$. The measurement range of light intensity: 0 100 lx, with measurement accuracy: $\pm 1 \mathrm{~lx}$. The measurement range of $\mathrm{CO}_{2}: 0 \sim$ $5000 \mathrm{mg} / \mathrm{m}^{3}$, with measurement accuracy: $\pm 50 \mathrm{mg} / \mathrm{m}^{3}$ ), wind speed (HD403TS2, Italy DELTA Co. Ltd. The measurement range: $0.08 \sim 5.0 \mathrm{~m} / \mathrm{s}$, with measurement accuracy: $\pm 0.2 \mathrm{~m} / \mathrm{s}$ ) and dust concentration (DS-300, Shenzhen Blue Control Co. Ltd. The measurement range: $0 \sim 50 \mathrm{mg} / \mathrm{m}^{3}$, with measurement accuracy: $\pm 0.5 \mathrm{mg} / \mathrm{m}^{3}$ ) were connected to the device by RS- 485 bus. All sensors have been calibrated before leaving the factories.

The device was powered by the power management module included a DC12V 48AH cell group with the corresponding power conversion circuit, and equipped with human-machine interface module included LCD and keyboard to realize the sample data real-time displaying and the configurable sampling period setting. The environment data could store in SD card combining with SD card data storage module and the real-time clock module, and also could send data to the remote server with GPRS wireless module (Xiamen Caimore Communication Technology Co.Ltd). The server monitoring software was developed based on SQL Server 2008, ASP. Net and visual studio 2010 web platform. It realized the real-time storage of environmental parameters information, user management, safety inspection, forms and statements establishment. The user could convenient query the henhouse environment parameters in real-time through the web page or intelligent mobile APP (Figure 1). Other egg quality measuring instruments were also used in this experiment, such as egg quality multi-function tester EMT-5200, eggshell strength tester, vernier caliper, and so on [5].

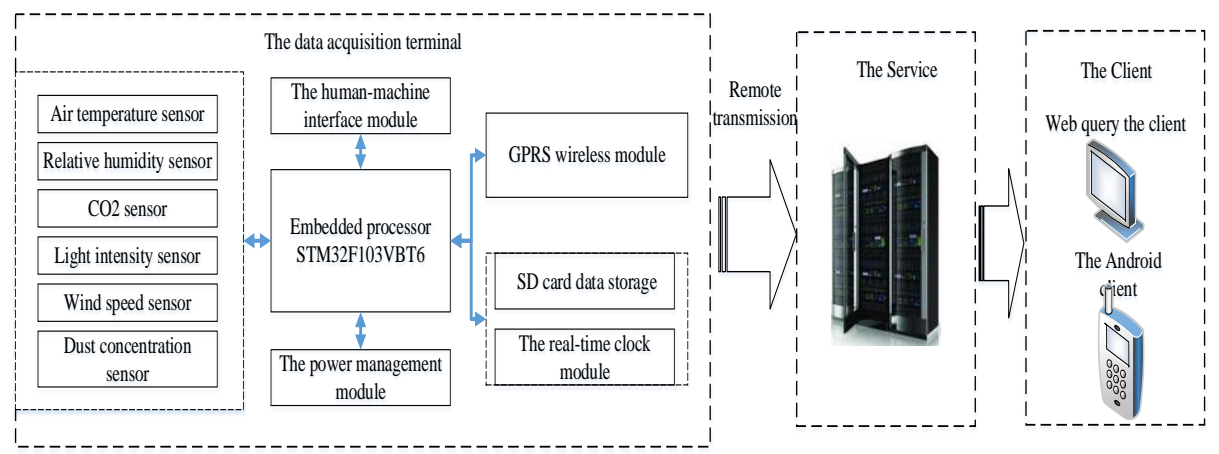

Fig. 1. The diagram of intelligent environmental monitoring device

\subsection{The design of environmental monitoring experiment}

The experiment was conducted from January 1 to February 12, 2017. The temperature, relative humidity, $\mathrm{CO}_{2}$ concentration, light intensity, wind speed and dust concentration of different points in the hen house were monitored. From the wet curtain end to the fan end, 3 points were measured which were $13.0 \mathrm{~m}, 39.0 \mathrm{~m}, 65.0$ $\mathrm{m}$ (L13.0, L39.0, L65.0) of 4 aisles, respectively. Meanwhile, 4 points of $0.6 \mathrm{~m}, 1.3 \mathrm{~m}$, 
$2.0 \mathrm{~m}$ and $2.6 \mathrm{~m}(\mathrm{H} 0.6, \mathrm{H} 1.3, \mathrm{H} 2.0$ and H2.6) from the ground were measured each aisle (Figure 2) [5,6].

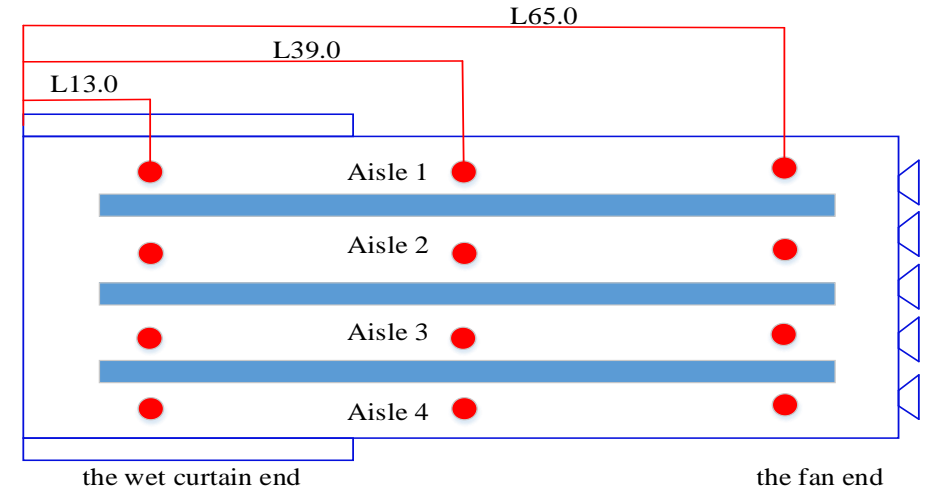

(a) The diagram of longitudinal henhouse aisles sampling points

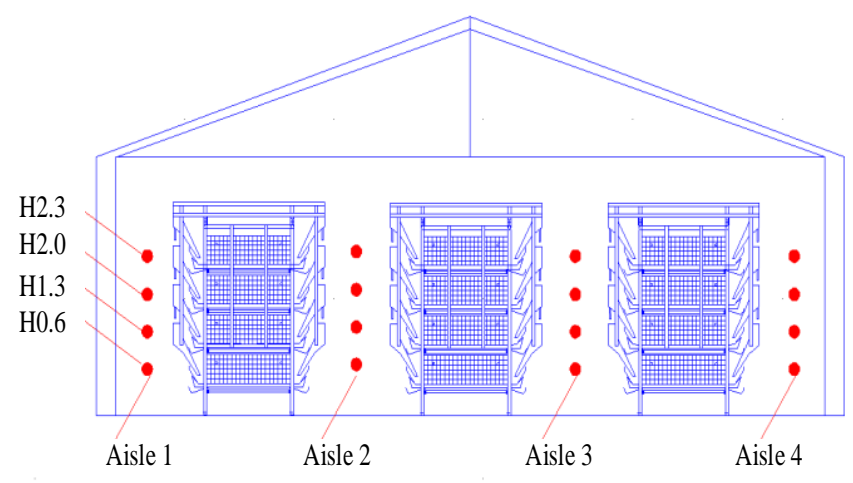

(b) The diagram of transverse henhouse aisle sampling points

Fig. 2. The diagram of henhouse aisle sampling points

During the experiment, the number and the weight of eggs produced by 5 single cage laying hens in the measurement points were measured every day. The egg quality measured at the end of the experiment, which collected 2 eggs in single cage and 10 eggs for each measuring point. The egg quality measuring items included egg shell strength, egg shape index, haugh unit [7]. The measuring methods were carried out according with the technical manual of livestock and poultry genetic resources formulated by the National Genetic Resources Commission [8]. 


\subsection{Statistical analysis}

The experimental data were processed by the Microsoft office excel. The descriptive statistical parameters were calculated with by SPSS 20.0. The difference significance test was analyzed by single factor variance, and the LSD method was used in multiple comparisons. The data in the following tables mean average plus or minus standard deviation. When $\mathrm{P}<0.05$, there was a statistically significant difference in the confidence interval of $95 \%$. When $\mathrm{P}<0.01$, there was a statistically significant difference in the $99 \%$ confidence interval [9].

\section{Results and Discussion}

\subsection{Analysis of environmental quality and laying performance in longitudinal measuring points}

The environmental quality in longitudinal measuring points of hen house was shown in Table 1. It could be seen from table that the average temperature, relative humidity, wind speed, $\mathrm{CO}_{2}$ concentration and dust concentration were $15.67{ }^{\circ} \mathrm{C}, 66.12 \%, 0.10$ $\mathrm{m} / \mathrm{s}, 2918.33 \mathrm{mg} / \mathrm{m}^{3}$ and $7.33 \mathrm{mg} / \mathrm{m}^{3}$ respectively. The average temperature and $\mathrm{CO}_{2}$ concentration from the wet curtain end to the fan end of the hen house were gradually increasing [10]. The temperature and $\mathrm{CO}_{2}$ concentration of determination point L13.0 $\mathrm{m}$ were significantly lower than that of the $\mathrm{L} 39.0 \mathrm{~m}$ and $\mathrm{L} 65.0 \mathrm{~m}(\mathrm{P}<0.05)$. The difference of wind speed among the longitudinal measuring points (L13.0 m, L39.0 m, and $\mathrm{L} 65.0 \mathrm{~m}$ ) was not significant $(\mathrm{P}>0.05)$. The relative humidity of L65.0 $\mathrm{m}$ was significantly lower than that of L13.0 m and L39.0 m $(\mathrm{P}<0.05)$. The dust concentration of L13.0 m was significantly higher than that of L39.0 m and L65.0 m $(\mathrm{P}<0.05)$.

Table 1. The environmental quality parameters change in longitudinal measuring points

\begin{tabular}{cccccc}
\hline $\begin{array}{c}\text { Sampling } \\
\text { points }\end{array}$ & $\begin{array}{c}\text { Temperature } \\
\left({ }^{\circ} \mathrm{C}\right)\end{array}$ & $\begin{array}{c}\text { Relative } \\
\text { humidity } \\
(\%)\end{array}$ & $\begin{array}{c}\text { Wind } \\
\text { speed } \\
(\mathrm{m} / \mathrm{s})\end{array}$ & $\begin{array}{c}\mathrm{CO}_{2} \text { concentration } \\
\left(\mathrm{mg} / \mathrm{m}^{3}\right)\end{array}$ & $\begin{array}{c}\text { Dust } \\
\text { concentration } \\
\left(\mathrm{mg} / \mathrm{m}^{3}\right)\end{array}$ \\
\hline $\mathrm{L}_{13.0 \mathrm{~m}}$ & $14.37 \pm 2.92^{\mathrm{a}}$ & $65.67 \pm 10.78^{\mathrm{ab}}$ & $0.10 \pm 0.03^{\mathrm{a}}$ & $2570.17 \pm 479.56^{\mathrm{a}}$ & $6.78 \pm 3.56^{\mathrm{a}}$ \\
$\mathrm{L}_{39.0 \mathrm{~m}}$ & $15.65 \pm 2.61^{\mathrm{b}}$ & $67.97 \pm 10.60^{\mathrm{a}}$ & $0.09 \pm 0.02^{\mathrm{a}}$ & $3013.56 \pm 642.55^{\mathrm{b}}$ & $7.62 \pm 3.07^{\mathrm{a}}$ \\
$\mathrm{L}_{65.0 \mathrm{~m}}$ & $16.99 \pm 2.37^{\mathrm{c}}$ & $64.73 \pm 9.97^{\mathrm{b}}$ & $0.11 \pm 0.03^{\mathrm{a}}$ & $3172.58 \pm 592.71^{\mathrm{b}}$ & $8.60 \pm 3.56^{\mathrm{a}}$ \\
\hline
\end{tabular}

Note: Different lowercase letters in the shoulder of the same column mean significantly different $(\mathrm{P}<0.05)$. The same as the following tables.

The laying performance and egg quality of laying hens were shown in Table 2. Under the same feeding management conditions, the difference of the laying rate and average egg weight among the measuring points of L13.0 m, L39.0 m and L65.0 m 
were not significant $(\mathrm{P}>0.05)$. The laying rate at the $\mathrm{L} 39.0 \mathrm{~m}$ was higher than that of $\mathrm{L} 13.0 \mathrm{~m}$ and $\mathrm{L} 65.0 \mathrm{~m}(\mathrm{P}>0.05)$ and the average egg weight at L39.0 $\mathrm{m}$ was lower than that of L13.0 $\mathrm{m}$ and L65.0 $\mathrm{m}(\mathrm{P}>0.05)$. The difference of eggshell strength, egg shape index, haugh unit among the longitudinal points at L13.0 m, L39.0 m and L65.0 $\mathrm{m}$ were not significant $(\mathrm{P}>0.05)$.

Table 2. The laying performance and egg quality in longitudinal measuring points

\begin{tabular}{cccccc}
\hline $\begin{array}{c}\text { Sampling } \\
\text { points }\end{array}$ & $\begin{array}{c}\text { Laying rate } \\
(\%)\end{array}$ & $\begin{array}{c}\text { Average egg } \\
\text { weight }(\mathrm{g})\end{array}$ & $\begin{array}{c}\text { Egg shape } \\
\text { index }\end{array}$ & $\begin{array}{c}\text { Shell } \\
\text { strength } \\
\left(\mathrm{kg} / \mathrm{cm}^{2}\right)\end{array}$ & Haugh unit \\
\hline $\mathrm{L}_{13.0 \mathrm{~m}}$ & $85.14 \pm 16.06^{\mathrm{a}}$ & $59.04 \pm 5.44^{\mathrm{a}}$ & $1.28 \pm 0.04^{\mathrm{a}}$ & $4.67 \pm 0.80^{\mathrm{a}}$ & $92.31 \pm 3.63^{\mathrm{a}}$ \\
$\mathrm{L}_{39.0 \mathrm{~m}}$ & $86.20 \pm 12.21^{\mathrm{a}}$ & $58.73 \pm 2.29^{\mathrm{a}}$ & $1.28 \pm 0.03^{\mathrm{a}}$ & $4.67 \pm 0.76^{\mathrm{a}}$ & $91.85 \pm 3.60^{\mathrm{a}}$ \\
$\mathrm{L}_{65.0 \mathrm{~m}}$ & $84.23 \pm 12.69^{\mathrm{a}}$ & $58.94 \pm 2.61^{\mathrm{a}}$ & $1.28 \pm 0.04^{\mathrm{a}}$ & $4.60 \pm 0.71^{\mathrm{a}}$ & $92.56 \pm 3.40^{\mathrm{a}}$ \\
\hline
\end{tabular}

\subsection{Analysis of environmental quality and laying performance in transverse measuring points}

The environmental quality and laying performance in transverse measurement points were shown in Table 3. With the increase height of cage layers, the temperature and $\mathrm{CO}_{2}$ concentration increasing gradually. The temperature in the measurement points at $\mathrm{H} 0.6 \mathrm{~m}$ and $\mathrm{H} 1.3 \mathrm{~m}$ were significantly lower than that of $\mathrm{H} 2.0 \mathrm{~m}$ and $\mathrm{H} 2.7 \mathrm{~m}(\mathrm{P}<$ 0.05). The temperature in $\mathrm{H} 0.6 \mathrm{~m}$ was the lowest, which was lower than the temperature of the measured point $\mathrm{H} 2.7 \mathrm{~m} 3.14{ }^{\circ} \mathrm{C}$. The relative humidity at $\mathrm{H} 0.6 \mathrm{~m}$ and $\mathrm{H} 1.3 \mathrm{~m}$ were significantly higher than that of $\mathrm{H} 2.0 \mathrm{~m}$ and $\mathrm{H} 2.7 \mathrm{~m}(\mathrm{P}<0.05)$.

The average light intensity was $52.25 \mathrm{~lx}$ and the light intensity at H0.6 m and H1.3 $\mathrm{m}$ were significantly higher than that of $\mathrm{H} 2.0 \mathrm{~m}$ and $\mathrm{H} 2.7 \mathrm{~m}(\mathrm{P}<0.05)$. Due to the experimental henhouse was reform from the old chicken coop and the plastic windows were installed on both sides wall, it led to the light intensity in the hen house was relatively too high to meet the requirement of national environmental quality standard of livestock and poultry farm (NY/T 388-1999) (30 1x) [11]. The $\mathrm{CO}_{2}$ concentration in different measuring points were higher than $1500 \mathrm{mg} / \mathrm{m}^{3}$ of the requirement of national environmental quality standard of livestock and poultry farm. The $\mathrm{CO}_{2}$ concentration at the highest measuring point on the cage $\mathrm{H} 2.7 \mathrm{~m}$ was up to $3722.97 \mathrm{mg} / \mathrm{m}^{3}$, which was significantly higher than other measuring points $(\mathrm{P}<$ $0.05)$. The dust concentration at $\mathrm{H} 2.7 \mathrm{~m}$ was significantly lower than that of other measurement points $(\mathrm{P}<0.05)[12]$.

Table 3. The environmental quality parameters change in transverse measuring points

\begin{tabular}{cccccc}
\hline $\begin{array}{c}\text { Sampling } \\
\text { points }\end{array}$ & $\begin{array}{c}\text { Temperature } \\
\left({ }^{\circ} \mathrm{C}\right)\end{array}$ & $\begin{array}{c}\text { Relative } \\
\text { humidity } \\
(\%)\end{array}$ & $\begin{array}{c}\text { Wind } \\
\text { speed } \\
(\mathrm{m} / \mathrm{s})\end{array}$ & $\begin{array}{c}\text { Light intensity } \\
(\mathrm{lx})\end{array}$ & $\begin{array}{c}\mathrm{CO}_{2} \text { concentration } \\
\left(\mathrm{mg} / \mathrm{m}^{3}\right)\end{array}$ \\
\hline $\mathrm{H}_{0.6 \mathrm{~m}}$ & $14.36 \pm 2.47^{\mathrm{a}}$ & $67.29 \pm 10.04^{\mathrm{a}}$ & $0.16 \pm 0.19^{\mathrm{a}}$ & $57.65 \pm 8.48^{\mathrm{a}}$ & $1991.65 \pm 689.25^{\mathrm{a}}$ \\
$\mathrm{H}_{1.3 \mathrm{~m}}$ & $14.83 \pm 2.26^{\mathrm{a}}$ & $69.18 \pm 9.26^{\mathrm{a}}$ & $0.06 \pm 0.11^{\mathrm{b}}$ & $64.25 \pm 7.06^{\mathrm{a}}$ & $2476.45 \pm 723.67^{\mathrm{b}}$ \\
$\mathrm{H}_{2.0 \mathrm{~m}}$ & $16.87 \pm 2.87^{\mathrm{b}}$ & $62.67 \pm 11.36^{\mathrm{b}}$ & $0.09 \pm 0.09^{\mathrm{b}}$ & $45.57 \pm 9.72^{\mathrm{b}}$ & $3190.49 \pm 690.80^{\mathrm{c}}$ \\
$\mathrm{H}_{2.7 \mathrm{~m}}$ & $17.50 \pm 2.63^{\mathrm{c}}$ & $63.72 \pm 10.55^{\mathrm{b}}$ & $0.08 \pm 0.15^{\mathrm{b}}$ & $43.67 \pm 8.41^{\mathrm{b}}$ & $3722.97 \pm 597.65^{\mathrm{d}}$ \\
\hline
\end{tabular}


The laying performance and egg quality of laying hens were shown in Table 4. At the different height of the cages, the laying rate at $\mathrm{H} 0.6 \mathrm{~m}$ was the highest, significantly higher than that of other cages $(\mathrm{P}<0.05)$. The laying rate at $\mathrm{H} 2.7 \mathrm{~m}$ was the lowest, significantly lower than that of other cages $(\mathrm{P}<0.05)$. In the average egg weight, the egg weight at $\mathrm{H} 0.6 \mathrm{~m}$ was significantly higher than the average egg weight at $\mathrm{H} 2.7 \mathrm{~m}(\mathrm{P}<0.05)$. There was no significant difference of eggshell strength, egg shape index, haugh unit among at different cages height of $\mathrm{H} 0.6 \mathrm{~m}, \mathrm{H} 1.3 \mathrm{~m}, \mathrm{H} 2.0$ $\mathrm{m}$ and $\mathrm{H} 2.7 \mathrm{~m}(\mathrm{P}>0.05)[13,14]$.

Table 4. Analysis of laying performance and egg quality in transverse measuring points

\begin{tabular}{cccccc}
\hline $\begin{array}{c}\text { Sampling } \\
\text { points }\end{array}$ & $\begin{array}{c}\text { Laying rate } \\
(\%)\end{array}$ & $\begin{array}{c}\text { Average egg } \\
\text { weight }(\mathrm{g})\end{array}$ & $\begin{array}{c}\text { Egg shape } \\
\text { index }\end{array}$ & $\begin{array}{c}\text { Shell } \\
\text { strength } \\
\left(\mathrm{kg} / \mathrm{cm}^{2}\right)\end{array}$ & Haugh unit \\
\hline $\mathrm{H}_{0.6 \mathrm{~m}}$ & $90.69 \pm 8.50^{\mathrm{a}}$ & $60.00 \pm 3.25^{\mathrm{a}}$ & $1.28 \pm 0.04^{\mathrm{a}}$ & $4.68 \pm 0.74^{\mathrm{a}}$ & $92.57 \pm 2.84^{\mathrm{a}}$ \\
$\mathrm{H}_{1.3 \mathrm{~m}}$ & $84.39 \pm 12.31^{\mathrm{b}}$ & $59.43 \pm 2.29^{\mathrm{ab}}$ & $1.28 \pm 0.04^{\mathrm{a}}$ & $4.56 \pm 0.80^{\mathrm{a}}$ & $91.84 \pm 3.33^{\mathrm{a}}$ \\
$\mathrm{H}_{2.0 \mathrm{~m}}$ & $85.72 \pm 9.78^{\mathrm{b}}$ & $58.74 \pm 2.68^{\mathrm{b}}$ & $1.27 \pm 0.04^{\mathrm{a}}$ & $4.65 \pm 0.70^{\mathrm{a}}$ & $92.25 \pm 4.21^{\mathrm{a}}$ \\
$\mathrm{H}_{2.7 \mathrm{~m}}$ & $77.74 \pm 20.21^{\mathrm{c}}$ & $56.76 \pm 5.53^{\mathrm{c}}$ & $1.28 \pm 0.04^{\mathrm{a}}$ & $4.67 \pm 0.82^{\mathrm{a}}$ & $92.15 \pm 3.54^{\mathrm{a}}$ \\
\hline
\end{tabular}

\subsection{Correlation analysis of henhouse environmental quality}

The analysis of henhouse environmental quality was shown in Table 5. It showed that in the enclosed henhouse with four overlap tiers cages, the temperature in the winter was significantly negatively correlated with the relative humidity $(\mathrm{P}<0.01)$, which was positively correlated with $\mathrm{CO}_{2}$ concentration $(\mathrm{P}<0.01)$. The relative humidity was significantly negatively correlated with $\mathrm{CO}_{2}$ concentration and wind speed $(\mathrm{P}<$ $0.01)$. The concentration of $\mathrm{CO}_{2}$ was significantly negatively correlated with wind speed $(\mathrm{P}<0.01)[15]$.

Table 5. The correlation analysis of laying house environment parameters in winter

\begin{tabular}{lccccc}
\hline & Temperature & $\begin{array}{c}\text { Relative } \\
\text { humidity }\end{array}$ & $\begin{array}{c}\mathrm{CO}_{2} \\
\text { concentration }\end{array}$ & $\begin{array}{c}\text { Wind } \\
\text { speed }\end{array}$ & $\begin{array}{c}\text { Dust } \\
\text { concentration }\end{array}$ \\
\hline Temperature & & & & & \\
Relative humidity & $-0.473^{* *}$ & & & & \\
$\mathrm{CO}_{2}$ concentration & $0.508^{* *}$ & $-0.202^{* *}$ & & & \\
Wind speed & -0.056 & $-0.324^{* *}$ & $-0.195^{* *}$ & & \\
Dust concentration & 0.128 & -0.011 & -0.019 & -0.123 & \\
\hline
\end{tabular}

Note: ** means extremely significantly different $(\mathrm{P}<0.01)$.

\section{Conclusions}

In conclusion, the environment parameters such as temperature, relative humidity, light intensity, $\mathrm{CO}_{2}$ concentration, wind speed, dust concentration at the different measuring points were different. The average temperature and $\mathrm{CO}_{2}$ concentration 
from the wet curtain end to the fan end of the henhouse were gradually increasing. The result shows the consistency of environmental parameters in different positions of chicken coop is poor and the environment control system needs to be improved. Because the light intensity in the henhouse was relatively too high, the henhouse windows should be upgraded to reduce the light intensity to a reasonable range, which can meet the requirement of national environmental quality standard of livestock and poultry farm.

Additionally, according to the measurement experiment of egg quality in henhouse different positions, it can be seen that different environmental quality will affect the performance of laying hens. In order to provide a good environment for the laying hens, it is necessary to coordinate the contradiction between ventilation and heat preservation. And under the premise of keeping the temperature suitable, the ventilation rate should be increased.

Acknowledgments. The authors thank the financial support by National Key Research and Development Program (2016YFD0800901-03); National Key Technology Research and Development Program of the Ministry of Science and Technology of China (2014BAD08B11); Program 863 (SS2013AA102302). And thank Anhui Jinan poultry Co. Ltd for providing experimental conditions.

\section{References}

1. Kuang, W., Liu, H., Yao, Y., Xi, Z.: The monitoring and analysis of cascade cage laying house environmental quality and laying performance. China Poultry. 39(01):64-65 (2017)

2. Shen, L., Niu, J., Liu, W., Yang, W., Li, H.: Study on distribution characteristics of Environmental quality parameters in broiler house with three-overlap cages. China Poultry. 38(18):37--41 (2016)

3. Troubleyn, E., Moerman, I., Demeester, P.: QoS challenges in wireless sensor networked robotic. Wireless Personal Communications. 70(3): 1059--1075 (2013)

4. Sharma V., Kumar, R.: A cooperative network framework for multi-UAV guided ground Ad Hoc networks, Journal of Intelligent and Robotic Systems. 77(3/4): 629--652 (2015)

5. Li, H., Li, M., Zhan, K., Yang, X., Weng, S., Yuan, Y., Chen, S., Luo, W., Gao, H.: Intelligent monitoring system for laminated henhouse based on Internet of Things. Transactions of the Chinese Society of Agricultural Engineering. 31(Supp.2):210--215 (2015)

6. Li, L., Huang, R., Huo, L., Li, J., Chen, H.: Design and experiment on monitoring device for layers individual production performance parameters. Transactions of the Chinese Society of Agricultural Engineering. 28(4):160--164 (2012)

7. Mirzaee-Ghaleh, E., Omid, M., Keyhani, A., Dalvand, M.J.: Comparison of fuzzy and on/off controllers for winter season indoor climate management in a model poultry house. Computer and Electronics in Agriculture. 110:18--195 (2015)

8. Chen, W.S.: Technical Manual of Farm Animal Genetic Resource Survey. China Agriculture Press, Beijing (2005)

9. Wu, J., Zhan, K., Li, J., Liu, W., Chen, G., Zhu, Y.: Effects of different cage temperature on performance, egg quality and serum indexes of laying hens in summer. Animal Husbandry and Veterinary Medicine. 44(8): 34--37 (2012)

10. Lobeck, K. M., Endres, M. I., Janni, K. A., Fetrow, J.: Environmental Characteristics and Bacterial Counts in Bedding and Milk Bulk Tank of Low Profile Cross-Ventilated, 
Naturally Ventilated, and Compost Bedded Pack Dairy Barns. Applied engineering in agriculture. 28(1): 117--128 (2012)

11. Quality Standards Office of Ministry of Agriculture of the People's Republic of China: NY/T388 -1999. National environmental quality standard of livestock and poultry farm. China Agriculture Press. Beijing (2008)

12. Wang, Y., Shi, H., Wang, Y., Li B.: Effect of air inlets situation on microenvironment of layer house in winter. China Poultry, 38(16):38--42 (2016)

13. Xin, H., Gates, R.S., Green, A.R., Mitloehner, F.M., Moore, P.A., Wathes, C.M.: Environmental impacts and sustainability of egg production systems. Poultry Science. 90 (1), 263--277 (2011)

14. Xi, L., Wang, Y., Chang, J., Li, P.: Effect of housing range model with Perches on production performance, egg quality and immune function of layer hens. China Animal Science and Veterinary Medicine. 41(115):24--28 (2014)

15. Zhao, Y., Shepherd, T.A., Li, H., Xin H.: Environmental assessment of three egg production systems-Part I: Monitoring system and indoor air quality. Poultry Science. 94(3): 518--533 (2015) 